\title{
Paul Tillich’s Marxism
}

\author{
Robert Dole \\ Université du Québec à Chicoutimi, Chicoutimi, Québec, Canada
}

\begin{abstract}
A new, objective reading of Paul Tillich's political writings reveals that he was an ideological ally of Russian Communists. In 1933, he was fired by the Nazis from his position of professor of philosophy at the University of Frankfurt because of his Marxist manifestation, Die sozialistische Entscheidung (The Socialist Decision), which he did not allow to be translated into English during his lifetime. His pro-American, anti-Russian discourse was simply a subterfuge to hide his fundamental loyalty to the international Marxist movement, a subterfuge required in order to protect his career in American universities.
\end{abstract}

Keywords: Marxism, socialist apocalypse, Cold War

\section{Introduction}

Considered by many to be "the greatest theologian since Augustine" (Cali, 1996, p. 19), Paul Tillich (1886-1965) was also a Marxist philosopher. He combined two major trends of German thought, Lutheran theology and Marxist dialectics, in his affirmation that "Jesus was the first socialist" (Tillich, 1971, p. 40). The socialism that Tillich had in mind was not like that of Bernie Sanders, but rather meant a total overthrow of American capitalist imperialism by an international Marxist revolution, in which the proletariat would seize the power from the bourgeoisie.

\section{The Socialist Decision}

Tillich's book Die sozialistische Entscheidung (The Socialist Decision) was published in early 1933, the same year in which the German people elected Hitler to be their leader. When the Nazis came to power, they immediately removed Tillich from his position of professor of philosophy at the University of Frankfurt precisely because his book makes it clear that he was an ideological ally of the Communists. Tillich was quite rightly proud to have been the first non-Jewish professor to be fired by the Nazis. His lifelong opposition to Nazi barbarism deserves universal admiration.

Many Christians, however, would find it difficult to share Tillich's idea that socialism represents the fulfillment of Christian eschatological expectation. His book contains many Marxist ideas with which any Communist ideologue in Moscow would have been in full agreement. Here are a few samples:

The proletarian struggle against liberalism is a struggle against the bourgeois class rule that was erected with the help of liberalism. (Tillich, 1977, p. 53)

The proletariat is just as much a creation of socialism as socialism is a creation of the proletariat. (Tillich, 1977, p. 62)

Robert Dole, Ph.D., Professor, Université du Québec à Chicoutimi. Robert Dole is the author of four books: Le Cauchemar américain, Comment réussir sa schizophrénie, Mon Allemagne and What Rough Beast. He is a retired professor of English at the Université du Québec à Chicoutimi. 
Communism does not believe in any form of progress on the soil of bourgeois society. It believes in the leap, the wholly new that is only possible through a complete social revolution. (Tillich, 1977, p. 70)

The structure of capitalism itself drives towards its transmutation into socialism, towards the classless society. (Tillich, 1977, p. 109)

The demand for a "dictatorship of the proletariat" can be understood as a call for the abolition of a pseudo-democracy that conceals bourgeois class domination. (Tillich, 1977, p. 142)

The only way that Tillich's socialism differs from orthodox Communism is its religious aspect, since Tillich thought that the socialist revolution would be the fulfillment of Christian eschatological expectation. He refers to "the prophetic expectation of a millennium" (Tillich, 1977, p. 132), "an intervening world catastrophe" (Tillich, 1977, p. 110), which would simply be the apocalypse prophesied in the Bible, carried out by progressive forces around the world and resulting in the victory of socialism over capitalist imperialism. God would intervene in world history to bring about both the victory of the proletariat in its struggle against the bourgeoisie and the fulfillment of the eschatological expectation of orthodox Christian theology.

The missing element in Tillich's Christian apocalypse is the advent of the Second Coming of Christ, who, according to the Bible, is to bring about the apocalypse. Tillich refers to such a person in The Socialist Decision:

Socialism's adopting of the bourgeois interpretation of human nature and its consequent exclusion of the "center" from its image of the human has caused, for example, the underestimation of the charismatic personality, i.e. the person who carries power of conviction by virtue of his being, his spiritual-vital center, quite apart from his rational formation or standing. (Tillich, 1977, p. 74)

This “charismatic personality” would play the role of Messiah in Tillich’s Marxist apocalypse. My idea that Tillich was hoping to find someone whom he could designate as being the socialist Messiah is confirmed by his widow, Hannah Tillich, who writes:

One of Paulus's marital jokes was to insist that I was his "second best." He called his first best his "cosmic reservation.” A first best did not exist on earth, he said, but one must reserve a place for the great unknown One who might come, as the Messiah might come at any moment to the waiting Jews. (Tillich, 1973, p. 104)

Tillich's Messiah would have to be an American who would denounce American capitalist imperialism and support the international Marxist revolution, since, as it says in the Bible, "No prophet is accepted in his own country" (Luke 4:24). If Tillich had succeeded in finding his American Messiah, the German people would have given to the history of the twentieth century not only Adolf Hitler but also a new Christ.

\section{Other Socialist Writings}

Throughout his long career as a theologian and philosopher, Tillich made several other statements that reveal his fundamental loyalty to international Communism. They are worth citing here.

In his essay "Religious Socialism”, Tillich admits to having a certain admiration for Russian Communism. He says: "The romantic type which identifies religion and socialism seems, finally, to have found a soil that has been intellectually and historically prepared for it in Russia” (Tillich, 1971, p. 45).

In his essay entitled "The State as Expectation and Demand", Tillich shows his approval of Marxist dictatorships. He declares: "Dictatorship appears to be the radical antithesis of democracy, but it is not. Dictatorship is based on democracy” (Tillich, 1971, p. 110). After the horrors perpetrated by Vladimir Lenin, 
Joseph Stalin, Nicolae Ceausescu, Erich Honeker, and Kim Jong-un, many people might find it difficult to believe that a theologian who favoured Marxist dictatorships was indeed divinely inspired.

Finally, in Tillich's book A History of Christian Thought, we find this curious sentence: "The so-called 'iron curtains' which we build to a certain extent by not admitting books from the East, etc., are attempts to keep the people in one definite tradition and to prevent it from touching other traditions” (Tillich, 1967, p. 140). Of course this idea is historically false, since it has always been possible in the West to purchase books published in the East. The works of Marx, Engels, Lenin and Stalin have always been available to those who want to buy them. The most visible sign of the Iron Curtain was the Berlin Wall, which was built by Communists to prevent people from fleeing the socialist countries of Eastern Europe.

\section{Conclusion}

During the thirty-two years that Tillich taught in American universities, from 1933 until his death in 1965, few people could see the paradox in his criticizing capitalism while praising the United States, the bastion of world capitalism, and praising socialism while criticizing the Soviet Union, the bastion of world socialism. It is my belief, and I think that my quotations from him prove it, that Tillich maintained a fundamental loyalty to the international Marxist movement throughout his entire life. It is a basic principle of Marxist ethics that any action is morally correct if it advances the cause of the socialist revolution. In Tillich's case this could have meant that he thought that it was ethically justifiable to profit to a maximum from American capitalism, to enjoy being venerated by countless naïve American Christians, and at the same time to look forward to the collapse of American capitalist imperialism during a Marxist revolutionary apocalypse.

For Tillich's untold American admirers, it would have been unthinkable that he might have been on the side of Russian Communists during the Cold War. Today, fifty-one years after his death and twenty-seven years since the end of the Cold War, Tillich scholars should have the courage to think the unthinkable.

We should bear in mind that for Tillich, the United States, the British Empire and France were mortal enemies during his very traumatic experiences in the First World War in eastern France. I believe that on some deep level of his psyche, Tillich remained a patriotic German and considered his sojourn in America to be a forced exile in the land of his erstwhile foe.

\section{References}

Cali, G. (1996). Paul Tillich first-hand: A memoir of the Harvard years. Chicago: Exploration Press.

Tillich, H. (1973). From time to time. New York: Stein and Day.

Tillich, P. (1967). A history of Christian thought. New York: Simon and Schuster.

Tillich, P. (1971). Political expectation. Macon, Georgia: Mercer University Press.

Tillich, P. (1977). The socialist decision. New York: Harper and Row. 